\title{
Perspectivas sobre o II Fórum Social Mundial
}

\section{VIRGÍLIO CAIXETA ARRAES}

Há alguns anos, Ignacio Ramonet, editor do Le Monde Diplomatique, chamou de "pensamento único" o conjunto de interesses do capital internacional, que se punha perante o mundo como universal. Propagado pelos organismos internacionais, meios de comunicação, universidades, centros de pesquisa, esta forma de pensar colocava o econômico acima do político, procurando reduzir as relações humanas a questões meramente quantitativas.

Amparado pelo fim da Guerra Fria, com derrota e extinção subseqüente da União Soviética, esse novo dogmatismo sintetizou ao grande público uma plataforma que se tornou conhecida como o Consenso de Washington, que, entre outras coisas, prescrevia livre comércio, privatizações, diminuição do Estado do bem-estar social, redução de direitos trabalhistas, apatia pelos custos ecológicos etc.

A aplicação desse ideário se deu de forma vigorosa na América Latina, a partir de meados dos anos 80 , onde os governantes de países recém-democratizados precisavam de apoio internacional para fortalecer seu processo de legitimação interna. Com as finanças ruins, a maior parte necessitava de investimentos estrangeiros para equilibrar-se, o que significava, em muitos casos, novos empréstimos para honrar os compromissos externos adquiridos na época dos regimes autoritários. Como contrapartida, o Primeiro Mundo, notadamente o anglo-saxão, solicitaria a incorporação das políticas neoliberais às práticas sociais públicas, já sobremaneira debilitadas.

Uma década depois, o quadro revelou-se catastrófico: o crescimento econômico veio timidamente, sem distribuição de renda; as remessas de lucros aumentaram, em função das privatizações desenfreadas e aumento real das tarifas; o desemprego consolidou-se, tornando-se estrutural; as políticas sociais, já escassas, diminuíram ainda mais, por causa da busca desenfreada de ganhos de competitividade; a violência incorporou-se ao cotidiano, em virtude da crescente exclusão social.

Para a América Latina, primeira referência geocultural do Brasil, o Banco Interamericano de Desenvolvimento estima para este ano um "crescimento" em torno de $1 \%$, invariavelmente abaixo da evolução demográfica da região. Durante a década de 90 , também perdida como a de 80 , o PIB da região ficou entre $0,6 \%$ e $1.3 \%$, resultado plenamente insatisfatório.

O $29^{\circ}$ período de sessões da CEPAL, realizado em Brasília, no mês de maio deste ano, confirmou os prognósticos negativos, ao divulgar que mais de um 
1/3 dos lares do continente é pobre. Países como Argentina, outrora paradigma do sucesso das reformas neoliberais, Colômbia e Equador tiveram seus índices de desemprego dobrados da década de 80 para a de 90, por exemplo.

Diante desse quadro, era natural que grupos sociais de toda a América Latina procurassem exprimir seu descontentamento com essas novas práticas político-econômicas públicas e privadas ao longo dos últimos anos. Assim, em 1996, quase dois anos depois da crise econômica que assolou o México e mostrou a vulnerabilidade da aplicação desse modelo, promoveu-se o I Encontro Americano pela Humanidade e contra o Neoliberalismo pela Frente Zapatista de Libertação Nacional do México. Em dezembro de 1999, a cidade de Belém do Pará promoveria o II Encontro. Geravam-se as condições políticas para a promoção de um evento de maior porte, que superasse o marco regional.

Desta maneira, em janeiro de 2001, o município de Porto Alegre promoveria o I Fórum Social Mundial (FSM), com a participação de cerca de 4 mil delegados oriundos de todos os continentes. Na época, chegou-se a comparar o evento como sendo a versão antípoda do Fórum Econômico de Davos, na Suíça - cujo primeiro encontro ocorreu em 1971. Tal comparação soa descabida porque o FSM não reuniu os detentores do poder mundial, nem se propôs à elaboração de uma “alternativa única”. Não foi também um evento antinorte-americano, apesar do papel que este país desempenha no atual processo mundial. Nem uma nem outra representaram a visão correta do evento, que pretendia ser um espaço para que variados grupos organizados apresentassem projetos que se contrapusessem ao rumo da globalização.

Em sua segunda realização, no início deste ano, o FSM recebeu mais de 12 mil delegados de mais de 120 países, com quase 3 mil e 500 jornalistas do mundo todo cobrindo o evento, o que mostra o aumento de sua importância e o descontentamento crescente do ponto de vista social e das relações solidárias entre os países.

Um de seus primeiros pontos com repercussão imediata, desde o ano passado, foi a discussão e adoção de medidas efetivas para o combate à pobreza no âmbito mundial, tema costumeiramente abordado de modo secundário nas reflexões neoliberais. Outro tópico importante foi a preocupação com a militarização, que vem sendo adotada como a solução de resolução de divergências em detrimento das negociações diplomáticas por meio de organismos internacionais.

Outras questões debatidas foram o impacto de blocos comerciais de grande porte, como a ALCA, sobre as relações trabalhistas e de distribuição de riqueza e a reforma das organizações internacionais como OCDE, FMI, OMC e BM, cujas metas impõem mais e mais sacrifícios de toda ordem às populações dos países a elas submetidos.

O êxito do evento foi considerável, tanto que se repetirá em Porto Alegre, e há proposta com vistas a sua realização na Índia, em 2004, e no continente 
africano, no ano subseqüente. No entanto, o grande desafio dos organizadores e participantes é a conversão das propostas em ações, cuja execução deve contar necessariamente com a mais ampla participação popular, de forma que a democracia, instaurada formalmente no século XX, em quase todo o mundo, passe no século XXI a ser substantiva, concretizando, assim, o seu significado teórico. 